\title{
An Early Romance: The Ideology of the Body in Mary Wollstonecraft's Writing
}

Like The Female Quixote, Mary Wollstonecraft's fiction has an ambivalent and uncertain relation to romance. On the one hand, her novels set up romance as what they especially, as women's work, must transcend; on the other, her work redefines the romantic as what might unsettle or elude the control of the male order. For Wollstonecraft, the very difference within the term itself reflects one of the problems of difference: whether such uncertainty unsettles or conserves, whether romance can provide (or even gesture to) an alternative to the world of the novel or can only repeat that world. Wollstonecraft's fiction, like Lennox's novel, does not solve this problem; what distinguishes between these two women writers is that, while Lennox's work emphasizes the necessary illusions of romance, Wollstonecraft's work instead investigates the price paid when the figure of the woman becomes the site for these double binds.

Let me begin this chapter with a gossipy anecdote about Matthew Gregory Lewis that Mrs. Oliphant tells in her Literary History. Lewis, you remember, was the author of that scandalous romance The Monk (1795). Yet the scandal Mrs. Oliphant recounts is not about The Monk at all, but quite other. After The Monk was published: "The family history of the Lewises [she writes] was . . . disturbed by an incident which plunged them into unimaginable 
terror. . . . [The mother] wrote a novel! When this terrible fact was known, her son, with a panic almost beyond words, rushed to pen and ink, to implore her to suppress it." ${ }^{1}$ Lewis warns his mother of the injuries publication of her novel would cause: his father would be shattered, his unmarried sister left an old maid, his married sister disgraced in her husband's family, and Lewis himself would have to flee to the Continent. Mrs. Oliphant suggests that Lewis objects to his mother's authorship because he fears it would coopt his own. He hears rumors that she has written The Monk and writes, "This goes more to put me out of humour with the book" than the critics' fury over it. ${ }^{2}$ But authorship is not alone at risk; Lewis fears his mother's writing would threaten her identity as a mother, and his own as her son (Oliphant depicts Lewis, in fact, as a mama's boy, whose relationship to his mother is central to his life). "I always consider a female author as a sort of half-man," ${ }^{3}$ Lewis writes to his mother, and his attempt to suppress her novel becomes an effort to avoid the gender uncertainties into which her writing would cast him: what would it mean if one's mother were half-man?

I present Monk Lewis here as an extreme example of a pervasive attitude. Although he is contemporary with Mary Wollstonecraft, he represents a view that is more than just locally and historically bound-more than the quaint prejudice of a certain class of the eighteenth-century that Oliphant, herself a famous nineteenthcentury writing mother, attempts (but too overdeterminedly) to argue that it is. Rather, this view points up some enduring structures of the unconscious and writing. That the greatest horror Monk Lewis could imagine was his mother writing provides the background for the discussion in this chapter of romance and women's writing. As a consideration of the relation between women and writing in Wollstonecraft's novels will suggest, such fears have to do with the horrors of uncertainty. A figure for this horror, woman in Wollstonecraft's fiction gets caught in a series of double binds-between novel and romance, motherhood and prostitution-that write themselves over her in an attempt to resolve 
themselves, to find a bridge for their uncertainties, but instead only mark her with this horror.

How do motherhood and women's writing figure in Mary Wollstonecraft's work? Certainly in her novels-Mary, A Fiction (published in 1788) and The Wrongs of Woman: or, Maria, A Fragment (1798) - Wollstonecraft presents those two rarities of fictionmothers and women writers-side by side. Mary opens with the story of the title character's mother; The Wrongs of Woman tells of Maria's mother, among others, and Maria's own motherhood is the focus of its story. Mary and Maria both write, and their lyrical effusions, as well as Maria's extended autobiographical narrative, are included in the texts.

Wollstonecraft's views on the problems of women's writing have seemed to her critics to appear most clearly through her treatment of romance. Mary Poovey argues that Wollstonecraft's novels set out to critique "romantic expectations" but get caught in romance despite themselves. ${ }^{4}$ Poovey condemns this collapse of Wollstonecraft's novels into romance because of its ultimate effect: by succumbing to romance, Wollstonecraft's novels fall into the patriarchal traps that Poovey thinks she is able to escape in $A$ Vindication of the Rights of Woman (published in 1792, it falls in between the two novels). "Finally," Poovey writes, "[in her novels] . . . what Wollstonecraft really wants is to achieve a new position of dependence within a paternal order of her own choosing." 5

I read Wollstonecraft's treatment of romance differently: I see romance aligned not with the paternal but with the maternal. Wollstonecraft explicitly thematizes this association in The Wrongs of Woman. She moves literally from what has come to be called the Name of the Father to the Name of the Mother by repeating, but significantly altering, a scene. Midway through her story, Maria, whose husband has stolen her baby, recounts the separation of a parent and child-in this case, an infant son, who lisps "Papa" to an absent father. ${ }^{6}$ Yet one ending of the unfinished Wrongs of Woman closes Maria's story with the restoration of her baby daughter,

\footnotetext{
${ }^{4}$ Mary Poovey, The Proper Lady and the Woman Writer: Ideology as Style in the Works of Mary Wollstonecraft, Mary Shelley, and Jane Austen (1984), 98.

5Poovey, The Proper Lady, 67.

6Mary Wollstonecraft, The Wrongs of Woman; or, Maria, A Fragment, in Mary and the Wrongs of Woman, ed. James Kinsley and Gary Kelly (1976), ch. 7, p. 131. All further references to this novel (hereafter abbreviated $W W$ ) will appear in the text.
} 
who utters instead "the word 'Mamma!'" (WW.Conclusion.203). In Wollstonecraft's fiction, mothers and daughters supplant fathers and sons. In this romantic ending (romantic in the traditional sense that it unrealistically fulfills a wish) mothers and daughters enjoy a union and happiness denied the men. Wollstonecraft goes on in her novels to link the maternal with romance even more securely, drawing on more senses of romance than just this traditional one. Yet we as readers still need to ask whether doing so makes any difference at all, especially for the woman writer.

In order to answer that question, I shall consider the other senses of the word "romance" that inform Wollstonecraft's collusion of the maternal and women's writing. Women as writers are linked to romance in another traditional sense of the term. Everyone is familiar, I think, with a common usage of the word "romance": immature writing, lacking the novel's complexity of form and sophistication of content-in its most generous usage, pure, artless, simple, naive writing. Traditional-especially eighteenthcentury-constructions of women sound very similar to this sense of romance: women are immature too, which makes them at best pure, artless, simple, and naive. As The Female Quixote has shown, this is one reason why romance as a form is usually considered proper to women; it is all that they are fitted to read or write.

On one level, Wollstonecraft seems to accept this equation between women and romance, and the derision it implies. Writing as an anonymous reviewer-presumably male-for the Analytical Review, she several times accounts for books that are "romantic unnatural fabrication[s]," as she calls them, marred both by bad writing and inexperience of life, by attributing them to the pen of "a very young lady." 7 She also distinguishes between romances and a different, better form, the novel, writing tongue-in-cheek of one "insipid, harmless production" that "we should have termed this a romance, if it had not been called a Novel in the title page." 8

Yet Wollstonecraft does not consistently accept the traditional definition of woman, or of romance. In A Vindication of the Rights of

7Review of The Cottage of Friendship: A Legendary Pastoral, By Silvania Pastorella, in A Wollstonecraft Anthology, ed. Janet Todd (1977), 223; see also Wollstonecraft's ironic deflation of another "very young lady" in her Review of The Vicar of Lansdowne; or, Country Quarters, A Tale, By Maria Regina Dalton (in Todd, Wollstonecraft Anthology, 221), and her query, "Why will young misses presume to write?" in her Review of The Fair Hibernian (Todd, Wollstonecraft Anthology, 224-25).

8Review of Albertina: A Novel, in Todd, Wollstonecraft Anthology, 224. 
Woman, she radically redefines woman, especially in relation to traditional assumptions about her maturity. Men treat women as if "they were in a state of perpetual childhood,"9 and confuse that state with "innocence" (VRW.4.153). Yet innocence is a "specious name" for ignorance, an enforced ignorance that is the cause of women's ills (2.100): they are not naturally childish; they are kept that way to bar them from a better state. After exposing this male sophistry that confuses and enslaves them, Wollstonecraft offers women a way to redefine themselves. She substitutes for the innocence they have been urged to cultivate its very opposite, "the treasure of life, experience" (2.114).

For Wollstonecraft, experience in general means education and exposure to the vicissitudes of life, a position of knowledge if not of mastery. But, more than that, the experience she values-the experience that the male authorities she criticizes in $A$ Vindication think is implied in any other, which is why they feel women must be kept ignorant/innocent-is especially sexual experience. In The Wrongs of Woman, Wollstonecraft suggests that "freedom of conduct has emancipated many women's minds" (WW.10.156), and it is her advocacy of women's sexual experience that immediately made her an anathema to an enduring critical tradition. Wollstonecraft argues that ignorance never equals sexual innocence: women barred from direct experience are actually the most corrupt for they debauch their minds reading romances (as Mary's mother is in danger of doing $\left.{ }^{10}\right)$, while the maid who falls can still remain mentally pure (VRW.8.241). Granting women sexual-bodily-experience is a way of protecting them from imaginative impurity, from the contagion of romance. In this interest, Wollstonecraft dispels the myth of woman's essential ignorance and immaturity in order to dissolve her seemingly natural connection to ignorant, immature romance.

In the development of her own fiction Wollstonecraft seems deliberately to move beyond romance. In its very opening, The Wrongs of Woman-meant as a novelistic continuation of $A$ Vindica-

9Mary Wollstonecraft, Author's Introduction, A Vindication of the Rights of Woman, ed. Miriam Brody Kramnick (1975), 81. All further references to this book (hereafter abbreviated $V R W$ ) will appear in the text.

${ }^{10}$ Mary Wollstonecraft, Mary, A Fiction in Mary and the Wrongs of Woman, ed. Kinsley and Kelly, ch. 1, pp. 2-3. All further references to this novel (hereafter abbreviated $M$ ) will appear in the text. 
tion $^{11}$ - proclaims itself an antiromance: Maria is in a madhouse, a place that is really horrible, not some silly haunted castle of "romantic fancy" (WW.1.75). This comparison is particularly telling, for Wollstonecraft's own less experienced work, her first novel, Mary, written before $A$ Vindication, has just such a castle, where its heroine loves to go and muse (M.4.9). Wollstonecraft seems aware that this first work is immature, naïve-traditionally romantic. Although in her preface to The Wrongs of Woman she deliberately calls it a novel (WW.73), the editors of the Oxford edition of Mary point out that "both title and preface [of that book] . . . carefully avoid the word novel"12 — no proclaiming a romance a novel in the title page for Wollstonecraft. While writing The Wrongs of Woman, Wollstonecraft admits in a letter that Mary is "a crude production . . . an imperfect sketch,"13 and Emily Sunstein, in her biography of Wollstonecraft, A Different Face, speaks for the majority of critics who indeed find Mary a "sentimental romance."14

As a novel, The Wrongs of Woman seems to take up where the romance, Mary, leaves off; Maria's situation critiques the deluded naïveté of the earlier heroine. Whereas Mary ends with the heroine living with her husband, The Wrongs of Woman opens with a heroine who has broken away from hers. Maria is older, savvy, and worldlywise in a way Mary never is: Mary never sleeps with her lover, for instance, while Maria does. Wollstonecraft inscribes the triumph of experience over romance into the very plot of The Wrongs of Woman. As a wife, Maria has been treated as an "idiot, or perpetual minor" (WW.11.159) to the extent that her husband has wrongly imprisoned her in the madhouse, kidnapped their daughter, and stolen her inheritance. In order to oppose the view of women that makes such treatment seem right and natural, Wollstonecraft has Maria write a narrative of her life, a story of her own painful road to experience, in which she sheds traditional- "romantic" as she calls them (7.128)— notions of her duties and abilities as a woman. Maria writes in order to aid and instruct her daughter, to help her also "gain experienceah! gain it-" (7.124).

Maria's book takes the place of-in fact, becomes-the experi-

${ }^{11}$ Kinsley and Kelly, Introduction, Mary and the Wrongs of Woman, xvi.

${ }^{12}$ Kinsley and Kelly, Introduction, ix.

13"To Everina Wollstonecraft, March 22d [1797]," in Collected Letters of Mary Wollstonecraft, ed. Ralph M. Wardle (1979), 385.

${ }^{14}$ Emily W. Sunstein, A Different Face: The Life of Mary Wollstonecraft (1975), 153. 
ence she wishes to hand on to her daughter. By making Maria a writer, and collapsing her text and her experience, Wollstonecraft underscores her new-unromantic-view of the possibilities for women's writing. The depiction of Maria necessarily reflects on Wollstonecraft as a woman writer: through Maria, she bolsters her own position as experienced-a position she certainly takes in $A$ Vindication-passing that legacy through her writing on to her readers, who fill in the place of Maria's lost daughter.

Where does motherhood fit into all this? For Wollstonecraft, maternity is crucially linked to women's sexual experience-maternity is sexuality's sign, what makes it manifest: the sexually experienced Maria is definitely a mother, though Mary never is. And Maria's (sexual) experience, which leads to her maternity, collapses into it, and becomes what enables her writing. Maria is a much more experienced and accomplished writer than Mary (she can give us a complete narrative rather than just Mary's fragments) partly because she is a mother. Maria's maternity provides the ability and occasion for writing: she writes to pass along her experience. But she also writes to maintain her very identity as a mother: she dedicates her narrative to her daughter, apostrophizing her in it, as an attempt to secure her (for that daughter may actually be dead, and Maria no longer a mother). Motherhood is not only the emblem of the woman writer in Wollstonecraft; Maria may be a mother only while she is writing.

Yet the mother, through her connection with writing, does not only move beyond romance in Wollstonecraft's fiction. The titles of her novels, by their repetition of variants of "Mary" (Wollstonecraft's own name, of course, as well as the name of the most renowned mother in European culture), suggest a continuity as well as a contrast between the books. While working on The Wrongs of Woman, Wollstonecraft, responding to her lover William Godwin's accusation of a "radical defect" in her writing, acknowledges an "original defect" in her mind, a sort of mother defect-a tendency toward romance. ${ }^{15}$

\footnotetext{
${ }^{15}$ For the defect in her writing, see "To William Godwin, [London] Sunday Morning [September 4, 1796]," in Collected Letters, 345. For the defect in her mind, see "To William Godwin, [London] Saturday Morning [May 21, 1797]," in Collected Letters, 394. The pertinent text there reads: "There is certainly an original defect in my mind-for the cruelest experience will not eradicate the foolish tendency I have to cherish, and expect to meet with, romantic tenderness."
} 
Romance does invade The Wrongs of Woman as much as it invades Mary. Maria, like Mary, is romantic: she confesses to her daughter peculiarities of temperament "which by the world are indefinitely termed romantic" (WW.7.128). In The Wrongs of Woman, it is the world surrounding Maria, particularly her husband, who more often than the narrative itself denounces Maria's romance (11.161; $12.167,169)$. Because it is Maria's brutish husband who dismisses as romantic all of her best qualities-Maria notes that "romantic sentiments ... was the indiscriminate epithet he gave to every mode of conduct or thinking superior to his own" (12.167)-romance also becomes a sign of the narrative's approbation.

This instability in the attitude toward romance in Wollstonecraft's writing grows out of an instability within the term itself. Wollstonecraft elsewhere writes of "romantic wavering feelings"; she collapses the "romantic and inconstant" (VRW.4.169). Romance takes on a new meaning, aligned with those qualities of indeterminacy; it comes to stand for instability itself and hence becomes what Wollstonecraft calls "tantamount to nonsensical."16 Romance as nonsense becomes a valorized term in Wollstonecraft's novels, one associated, as is its more traditional and derisive meaning, with the maternal. Wollstonecraft directly connects the romantic and nonsensical, for example, in her own paean to the imagination: the "mother of sentiment."17 Although romance and motherhood can stand opposed-the mother, through her experience, breaking away from the romantic-within this second sense the two are inseparable. This connection again leads away from experience: Wollstonecraft insisted on keeping her inexperienced "romantic" feelings in the face of the wiser experience and "judgment" of her first lover-Gilbert Imlay-because "they resemble the mother more than the father"18_that is, experience and judgment come more from the imagination, the province of romance she has earlier criticized.

Romance, nonsense, motherhood, and immaturity: to understand their connection in Wollstonecraft's writing we need for a moment to consider these terms in another context, for they also demarcate the category of the semiotic in the early writings of the psychoanalytic theorist Julia Kristeva. The semiotic is Kristeva's

16"To Gilbert Imlay, [Paris] September 22 [1794]," in Collected Letters, 263.

17 "To Gilbert Imlay, [Paris] September 22 [1794]," in Collected Letters, 263.

18"To Gilbert Imlay, [Le Havre] August 17 [1794]," in Collected Letters, 258-59. 
own move from the Name of the Father to the Mother; as Mary Jacobus argues, Kristeva substitutes the pre-Oedipal mother for the Oedipal father in terms of their relation to the origins of discourse. ${ }^{19}$ In Desire in Language, Kristeva yokes and opposes the semiotic to the symbolic. Kristeva's symbolic we can understand largely in Lacan's terms; she links it to meaning, signification, representation, the location of sense and of the subject, the entry into language brought about through the agency of the father and the threat of castration. The semiotic is impossibly, but necessarily, outside meaning and subjectivity, calling them into question (it is heterogeneous to signification, operates "through, despite, and in excess of it," and comes before or is outside of "the operating consciousness" of the subject created by the symbolic order ${ }^{20}$ ). Kristeva gestures to the impossible place of the semiotic by aligning it with (fantasies of) the pre-Oedipal: with immature archaic expression, "uncertain and indeterminate articulation," with the utterances of infants, and particularly with what she calls the maternal chora-the maternal body and its responses to the infant, which embody this antirepresentational, disruptive dimension ${ }^{21}$ (a dimension in which the literary critic Dianne Sadoff places that formless and undifferentiated realm that we call "in narrative terminology, the romance"22).

19Mary Jacobus, Reading Woman: Essays in Feminist Criticism (1986), 145.

20Julia Kristeva, Desire in Language: A Semiotic Approach to Literature and Art, ed. Leon S. Roudiez, trans. Thomas Gora, Alice Jardine, and Leon S. Roudiez (1980), 133.

21Kristeva, Desire in Language, 133. Jane Gallop, in her "The Phallic Mother: Fraudian Analysis" (The Daughter's Seduction: Feminism and Psychoanalysis [1982], 113-31), may be right in implying that the pre-Oedipal position is not just a fantasy for Kristeva but always risks becoming a developmental fact that seems to offer the mother as a solution to gender problems, as it does in the object-relations psychology on which Kristeva sometimes relies. For a discussion of the political effects of this and other elements in Kristeva's thought, see Jennifer Stone, "The Horrors of Power: A Critique of 'Kristeva,' " in The Politics of Theory: Proceedings of the 1982 Essex Conference, ed. Frances Barker, Peter Hulme, Margaret Iversen, Diana Loxley (1983), 38-48; Ann Rosalind Jones, "Julia Kristeva on Femininity: The Limits of a Semiotic Politics," Feminist Review 18 (November 1984): 56-73; Domna C. Stanton, "Difference on Trial: A Critique of the Maternal Metaphor in Cixous, Irigaray, and Kristeva," in The Poetics of Gender, ed. Nancy K. Miller (1986), 157-82; and Jacqueline Rose, "Julia Kristeva-Take Two," in her Sexuality in the Field of Vision (1986), 141-64. Rose argues that the semiotic is actually the least useful of Kristeva's categories; its problem is that it lends itself so easily to the kind of essentialism that this chapter explores, seeming to collapse woman/mother/body.

22Dianne F. Sadoff, Monsters of Affection: Dickens, Eliot and Brontë on Fatherhood (1982), 124. 
Jane Gallop does a canny, perverse, and, I think, sometimes incorrect reading of the problems of Kristeva's semiotic, the dangers of collapsing it with the maternal, of believing the mother controls it. ${ }^{23}$ Richard Klein, on the other hand, suggests-and I agree with him - that Kristeva actually constructs the maternal precisely around the very splitting, the doubleness of identity that Gallop argues it totalizes. ${ }^{24}$ Perhaps this doubleness will become clearer in a moment if I examine the semiotic in Wollstonecraft's writing as just one aspect of the mother, who is at the same time opposed to that character of herself.

Motherhood is associated with semiotic forces in The Wrongs of Woman from the start of the book, which opens with Maria confined within the madhouse. Her confinement there figures that other confinement, childbirth: Maria's imprisonment in the madhouse is the direct result of the birth of her daughter, heir to the fortune her husband wishes to possess. Similarly, another inmate, and fellow female artist, the "lovely warbler" whose songs Maria admires, underscores this interrelation of meanings: she has gone mad "during her first lying-in" (WW.2.88), as Wollstonecraft's own sister may have done. The madhouse figures the non-sense of the maternal chora, quite literally in the babble of the mad, "the burden of ... incessant ravings" (2.84) that is the constant background to Maria's story. The narrator likens Maria's situation to being "in a strange land, where the human voice conveys no information to the eager ear" (2.86), and Maria's ordering of her life in her autobiography is in reaction to, but called into question by, the linguistic chaos surrounding her. When the novel directly associates the breakdown of language and shattering of meaning with the maternal, its effects remain disruptive of order but can be rapturous as well as threatening: Maria's fervent observations on maternity "interrupt" her narrative (10.154), and those observations are so fervent because her pleasure in being a mother is "unutterable" (10.154).

Moreover, the mother is marked within Wollstonecraft's fiction not just through her presence but also through her absence. For although Wollstonecraft gestures to the mother more than is usual 
in fiction, the maternal space remains curiously vacant too. In describing Mary's mother, the narrator refers to her as a "mere nothing," one of the female "noughts" (M.1.2), and that is the position mothers occupy throughout Wollstonecraft's work: Maria's mother becomes important when she dies, and Maria's own motherhood is posited but never realized in her novel-her daughter almost immediately disappears and their time together is only a blank in the text. The mother is shadowy, not completely represented, because her place is outside the signifying order, unrepresentable.

Interruption, partial representation, becomes a narrative principle in the novel; The Wrongs of Woman is itself nonsensical, interrupted by violence as well as rapture, especially at its end, which is particularly fragmented, almost meaningless. In place of closure, Wollstonecraft presents competing and contradictory stories, most of which revolve around Maria's response to a new pregnancy (Wollstonecraft was herself pregnant again at the time and died shortly after giving birth). Such semiotic forces would indeed represent for a male critic a romantic "defect" in the woman writer, and in two senses: defect's sense of lack-the lack of sense in her writing, the nonsense of its language (Godwin particularly criticized Wollstonecraft's lack of control over language, her problems with grammar), playing on what a man would see as Wollstonecraft's own essential lack as a woman writer-and also defect's sense of desertion-the woman writer leaving the rank and file of the male (symbolic) order. In her preface to The Wrongs of Woman, Wollstonecraft emphasizes that the situation of maternity is the vehicle for such writing: she contrasts her book to ones in which maternity is bypassed altogether-male writing, books (perhaps by Richardson and Rousseau, from whom she distinguishes herself in the advertisement to Mary) that treat their heroines as if they had "just come forth highly finished Minervas from the head of Jove" (WW.73). Wollstonecraft's novel, on the other hand, is the product of a woman, and one that she suggests is fully formed in the rather formless state we receive it-she warns her readers against dismissing it as a mere sketch, as "the abortion of a distempered fancy" (73).

In Wollstonecraft's writing, then, the mother is double. She is both outside and inside romance: in command of language even to speaking new terms for her own self-definition, to breaking with 
the ignorance and immaturity of romance, and at the same time subverting the order and meaning of language, partaking of the romance of the infantile and unutterable.

At the beginning of this chapter, I questioned whether it made any difference for the woman writer to write under the Name of the Father or the Mother, to relocate the romantic with the maternal. The terms of my question, I think, provide for its answer, for difference is what is crucial, the mother's difference from herself; her connection with romance exposes that the mother in Wollstonecraft is both experienced and an inhabitant of a realm in which experience is meaningless. She is both the one who knows-the one Gallop calls the phallic mother-and the one outside of and undercutting knowledge-the maternal chora.

This self-division extends and dissolves the very category of Name: of language, and of writing. By moving from the father to the mother, we emphasize that naming, language, is not just the function of the transcendental signifier, the phallus, but also of the undertones and side-effects of signification-its babble and noise-that won't leave it alone, that call it into question. And the category of the mother, alternatively fixed and undercutting itself, is created by and reflects this very movement. The mother actually is what Monk Lewis fears-she is half man, partially constituted as a subject, within mastery and language. Maria's desire "to be a father, as well as a mother" (WW.13.180) to her daughter suggests Wollstonecraft's recognition of her double role. Locating the woman writer with motherhood, difference, and division allows her to make sense-and nonsense-within the paternal order, to work within it without completely accepting its rule. And that, I think, makes all the difference.

Directing my argument about the mother is what has become a standard critical move: the maternal is that which threatens a system of power-patriarchy or representation-and is cast out accordingly. Her absence shores up the system. And yet that system can never dispatch her because she is part of it. Or rather, I've made that system part of the maternal, relocating this play of difference within the mother-she is what is subverted as well as what subverts. But I want to push my argument a little further by asking, why the mother? What might be involved in using her as an emblem of difference, and what might be the problems of doing 
so? One objection might be that locating difference within the mother is a regressive fantasy of plenitude that actually collapses difference: she becomes the Mother who is-and therefore haseverything, a new appearance of an old friend, the Phallic Mother, and once again gets aligned with sameness, with the phallus. I'm intrigued by the collapse of difference implied in conjuring it, and would like to follow it, to get to the same place along a different route, by raising another objection we could make to the use of the maternal.

For isn't examining a text in terms of the category of the mother also a regression to a dangerous essentialism that feminist critics have been trying hard to avoid? Doesn't recourse to the mother simply collapse the woman with the body in the worst wayreduce her to the reproductive function that has always entrapped her? And isn't that especially risky when discussing women writers, since traditionally maternity has been the only type of experience they have been thought able to depict? I might respond to that objection by saying that my use of the term "motherhood" means something more than just experience. But one answer to whether the category of the mother sheers off into essentialism would have to be yes. And yet, why? And does that pose a problem?

I want to examine this collapse into the body and biology by turning again to Mary Wollstonecraft's writing. Writing about the body is particularly attractive to Wollstonecraft: Godwin quotes an introduction of hers to an early conduct book, in which she wishes that her audience were ready for stories about "the organs of generation." 25 Wollstonecraft's display of the body within her writing seems to be the offense for which her most vehement critic, the

25William Godwin, Memoirs of Mary Wollstonecraft, ed. W. Clark Durant (1927), p. 200. Godwin is quoting here from Wollstonecraft's "Introductory Address to Parents," in her Elements of Morality. The passage he quotes reads: "I would willingly have said something of chastity and impurity; for impurity is now spread so far, that even children are infected; and by it the seeds of every virtue, as well as the germ of their posterity, which the Creator has implanted in them for wise purposes, are weakened or destroyed. I am thoroughly persuaded that the most efficacious method to root out this dreadful evil, which poisons the source of human happiness, would be to speak to children of the organs of generation as freely as we speak of the other parts of the body, and explain to them the noble use which they were designed for, and how they may be injured. . . . [But] many people would have been shocked at tales, which might early in life have accustomed their children to see the dreadful consequences of incontinence; I have therefore been induced to leave them out" (200-201). 
Reverend Richard Polwhele, attacked her. In a note to his poem The Unsex'd Females (1797), he objects to that very conduct book piece: "Miss Wollstonecraft does not blush to say . . . that 'in order to lay the axe at the root of corruption . . . it would be right to speak of the organs of generation.' "26 Polwhele, however, only seems to be objecting to Wollstonecraft's attention to the body; what actually bothers him is how much she ignores it, how much she bucks the essentialism in which he grounds his attack. What is horrifying to him about what he calls Wollstonecraft's "new philosophical system" is that it "confounds the distinction of the sexes"27 - and Wollstonecraft does, in fact, write in $A$ Vindication that "the sexual distinction which men have so warmly insisted upon, is arbitrary" (13.318). For Polwhele, the difference between men's and women's bodies determines the difference between their minds: woman's weaker physique ensures what he calls her "comparative imbecility" 28 and "inferiority . . . in the scale of intelligence." ${ }^{29}$ For Polwhele, Wollstonecraft's "philosophy" is what unsexes hermakes it impossible to tell that she is female. Moreover, the implications of Wollstonecraft's system unsexes men as well: Polwhele misquotes Wollstonecraft, for according to Godwin's version of the text, she writes only that she is trying to "root out this dreadful evil" not that she wishes to "lay the axe at the root of corruption." Polwhele's misquotation shows that what bothers him about Wollstonecraft's system is the threat of castration. Rather than displaying the organs of generation in a way that shows clearly who's who, Wollstonecraft wants to mix up the boys and the girls. Polwhele goes on to write:

I shudder at the new unpictur'd scene, Where unsex' $\mathrm{d}$ woman vaunts the imperious mien;

Where girls, affecting to dismiss the heart, Invoke the Proteus of petrific Art. 30

Representation and essentialism go hand in hand: to depict something is to place it within sexual difference. What horrifies Pol-

26Richard Polwhele, The Unsex'd Females (1797), 11n.

27Polwhele, Unsex'd Females, 27n.

28Polwhele, Unsex'd Females, 20 .

29Polwhele, Unsex'd Females, 19n.

30Polwhele, Unsex'd Females, 19n. Polwhele calls such "unsex'd females" "the female Quixotes of the new philosophy" (7n). 
whele is that Wollstonecraft refuses to do this; she aligns herself instead with the "unpictur' $d$ " and "protean" rather than the "petrific."

Critics like Laura Mulvey and Mary Jacobus have continued the argument that any representation inscribes essentialist distinctions. ${ }^{31}$ Given this argument, the maternal as sign-even as sign for the unsignifiable-is only the extension of the logic of representation. For this very reason, French feminists collapse woman with her body, her maternity; by flaunting the maternal body, they expose the built-in essentialism of any structure of knowledge, disrupting its smooth and secret workings.

But another approach is to refuse such essentialist constructions of the maternal, to argue that representation-even the representation of the body-is just that: figurative, not literal. What distinguishes Mary Wollstonecraft's treatment of the body is that it is not about the body at all; it points, through Polwhele's reaction to it, to how the body becomes just another figure, a metaphor, in Polwhele's case an impossible fantasy of some clear-cut ground of reference-a fantasy that Wollstonecraft refuses. The body is a metaphor for something else for Wollstonecraft, as the shift from the literal to the figurative (in her advertisement to Mary) illustrates: "In an artless tale, without episodes, the mind of a woman, who has thinking powers is displayed. The female organs have been thought too weak for this arduous employment. . . . Without arguing physically about possibilities-in a fiction, such a being may be allowed to exist; whose grandeur is . . . drawn by the individual from the original source" (xxxi). In Mary, Wollstonecraft finally provides a tale of organs-female organs. But the mother, the "original source," of which they're an extension, is not the womb but the mind, and these organs produce thought-and stories-rather than children. The body becomes a metaphor for writing; the physical leads to the fictional. The oscillation between the literal and figurative-just as between the novel and romance, men and women, or the two aspects of the maternal-presents another pair of differences that can't quite be kept apart, that keep collapsing into each other. My first conclusion about the importance of the maternal for women's writing emphasized difference. I

31Laura Mulvey, "Visual Pleasure and the Narrative Cinema," Screen 16 (1975): 618, and Jacobus, Reading Woman, 110-36. 
want now to propose a different conclusion that emphasizes sameness. A move to the maternal is also a move to the same, a move that undercuts the distinctions between mother and father, literature and life, other and self. And Monk Lewis's and Polwhele's need for difference, their horror when it breaks down, are instructive: as readers and critics, we become no different from them if we don't recognize our similarity to them. Our own insistence on difference is, like theirs, to stave off a threat, the threat of the indeterminable, which undoes genre, gender, even identity, which, at least on one level, implicates us in categories from which we wish to distinguish ourselves. The category of women's writing, for example, although a useful fiction, in its reliance on supposedly clear-cut gender distinctions must be recognized as a fiction, a difference we impose for our own purposes. So, I would also say that the move from the paternal to the maternal actually makes no difference, if we keep in mind the ways they inhabit each other. But, in saying that, I'm not disagreeing with my earlier conclusion: I'm just saying the same thing.

\section{II}

But let me begin again. For this logic of repetition, this oscillation between sameness and difference, organized around women's writing, the mother, and the woman's body, takes another form as well: in a familiar logic, motherhood takes its meaning only through comparison and contrast with its supposed opposite. The oscillation between sameness and difference defining woman, giving meaning to her by giving meaning to her body, is also the oscillation between madonna and whore, another of those divisions that keep collapsing and re-forming. ${ }^{32}$ The figure of the pros-

32One difference between the madonna and whore rests in whether or not they (re)produce-the madonna is that virgin mother whose intact body yields a surprising production, while the body of the prostitute, repeatedly violated, yields nothing but more such exchanges. But the recognition of the empty exchanges the prostitute is made to represent does not necessarily uncover the supposed economic, historical, and material realities underlying women's cultural definition. Foucault's critique of the repressive hypothesis suggests a dynamic in which traditional culture actually itself emphasizes rather than ignores the prostitute; women's cultural construction seems even to depend on such divisions as those between madonna and whore. The preservation of these divisions acts to purge the category of maternity from what phallogocentric ideology perceives as contamination or 
titute, as much as the figure of the mother, seems to reduce woman to her body, to insist on the body as woman's essence, her material reality. And, as critics' responses to the split between the mother and the prostitute in Wollstonecraft's writing show, this particular division has been considered important because it introduces a material element of woman's construction that might otherwise be ignored: such critics emphasize the body-the prostitute's bodybecause they argue that insisting on it might uncover an important hidden essence, the necessity of material and economic factors to the construction of reality. Focusing on the prostitute, they imply, would reveal the ideology behind conventional forms, an ideology that makes writing romantic rather than realistic because it masks economic relations with erotic relations.

One approach to Wollstonecraft's writing might be to argue that her emphasis in it on the maternal body is a strategy meant to deflect or deny woman's identity as prostitute, and hence to deny her own implication as woman in what she called the system of "commerce." Her private letters to Imlay and her Letters Written during a Short Residence in Sweden, Norway, and Denmark show that she found such a system dangerously depersonalizing, and some feminist critics interested in a materialist critique argue that Wollstonecraft does attempt to ignore or occlude what the prostitute represents. $^{33}$ By ultimately ignoring the economic exigencies

threat, to make it part and upholder of that order, while the collapse of madonna and whore ensures that such categories need vigilant policing, hence making it seem as if it is woman, not the order itself, that is divided and threatened. Such cultural strategies also manage the supposed economic realities that an emphasis on prostitution is meant to uncover, for making it an economic question at all can play into a moral ideology that necessarily scapegoats the economic; think of the stereotypical logic (in Richardson in the contrast between Clarissa and the prostitutes with whom Lovelace houses her, in Dickens in Fagin's gang from whom Nancy must distinguish herself, and-still with us today-in the story of the Mayflower Madame) which emphasizes the fallen woman's supposed autonomy and responsibility, her choice of the (supposedly lucrative) career of prostitution over, say, honest death.

${ }^{33}$ She worries throughout this text that her reader "may think me too severe on commerce" (Mary Wollstonecraft, Letters Written during a Short Residence in Sweden, Norway, and Denmark, ed. Carol H. Poston [1976], letter 13, p. 119. See also letter 23, pp. 187-90, and letter 24, pp. 192-93). The "baleful effect of extensive speculations on the moral character" (letter 23, p. 190) she feels is such that businessmen must necessarily become like Maria's husband, imbruted by greed and display "till they term all virtue, of an heroic cast, romantic attempts at something above our nature" (letter 23, p. 187). 
pointed to by the very story of the prostitution of the woman's body, they argue, Wollstonecraft winds up back in old patriarchal traps, telling the same old story about women that the male order tells.

Yet Wollstonecraft's treatment of the prostitute-she discusses that figure in her reviews, in $A$ Vindication, and most obviously in her fiction, in the story of Jemima ${ }^{34}$-remains as complex and divided as her treatment of the mother; it points to the tensions within the construction of woman, available to us through divisions within the romantic forms connected to them. One way to consider how the figure of the prostitute gives form to such tensions in Wollstonecraft's writing is by considering it as a figure, a form, a body. Rather than simply accepting the materiality of this figure, however, as critics we might question why it is so often the symbol for the material. What does such use of the prostitute tell us about women's writing-not just about women's fiction, but about feminist criticism as well?

I want to return once more to the nineteenth century's reflections on the eighteenth, to the endurance of attitudes about the woman's body that attend different local representations of prostitution in those different centuries. "Novels with Purpose," an influential review written by Justin McCarthy in 1864 for the Westminster Review, responds to what it sees as a spate of novels about women's sexual corruption in terms familiar from Wollstonecraft's writing. McCarthy writes: "The best justification for the adoption of such topics . . . assuredly is that women may perhaps be thus redeemed from the possibility of remaining in that imbecile and ignorant condition which the romancist commonly regards as innocence, and which woman is so generally encouraged to cherish as her special virtue, even by those who are so earnest in describing it as the principal cause of her ruin." 35 Charlotte Brontë is one of the few women writers McCarthy cites as seeing through such specious innocence. Indeed, about fifteen years earlier, in Shirley, Brontë had

\footnotetext{
${ }^{34}$ For Wollstonecraft's short discussion of prostitution in her reviews, see her Review of The Evils of Adultery and Prostitution, Analytical Review 14 (September 1792): 100-102.

${ }^{35}$ [Justin McCarthy], "Novels with a Purpose," Westminster Review, n.s. 26 (July and October 1864): 45.
} 
complained about women's ignorance in terms that McCarthy's also echo: "Fathers! cannot you alter these things? . . . You would wish to be proud of your daughters and not to blush for them-then seek for them an interest and an occupation which shall raise them above the flirt, the manoeuvrer, the mischief-making tale-bearer. Keep your girls' minds narrow and fettered-they will still be a plague and a care, sometimes a disgrace to you." 36 McCarthy and Brontë are similar in blaming a false innocence that is really ignorance for women's corruption, but they cast that blame differently. Brontë puts it onto patriarchal society, making it the fathers' burden. McCarthy, sympathetic to Brontë's work and the problems it confronts, revises it nonetheless to make women's victimization their own charge. ${ }^{37}$

McCarthy does, however, recognize that the forces prompting women to fall are strong. Like Brontë, he sees that the very idea of woman is plotted, if not plotted against. Like hers, his reading points out the implicit narrative of ruin built into women's cultural construction. It is not surprising, both suggest even as they deplore it, to read so many stories of women who fall, since the

\footnotetext{
${ }^{36}$ Charlotte Brontë, Shirley, ed. Andrew and Judith Hook (1974), ch. 22, pp. 37879.
}

${ }^{37} \mathrm{McC}$ arthy shifts the blame through recourse to conventional assumptions about the woman's body. He specifically commends Brontë's informed and experienced depiction of her heroines not because it shows women's strength and shrewdness but because it shows "women and girls endowed with human passion" (McCarthy, "Novels with a Purpose," 49). And such "endowments," not surprisingly, refer to the body. McCarthy ends his essay by describing Brontë's attempts to present the passions as a literal stripping away of false dress: "A Parisian critic lately, when noticing some objections urged against the numerous undraped Graces, and Bacchantes, and Nymphs, and Ledas in the season's Exhibition, drily remarked that so long as vast skirts and hoops and spoon-bonnets endured, it was a relief to get a glimpse of the true outlines of womanhood under any circumstances. We own to something of a kindred feeling in regard to our English fiction" (49). In arguing this, McCarthy isolates one of the paradoxes undermining women's writing-how her attempt to write "true" womanhood (perhaps by attempting to disentangle her construction from the erotic, certainly part of Brontë's struggle, as it was of Wollstonecraft's) is seen nonetheless, even by a sympathetic male critic, in terms of the eroticized body. Defining woman in terms of her body keeps the woman responsible for her ruin, even as she tries to script plots that go beyond it: such a constraint maintains the logic of blaming the victim and follows in the tradition of "the woman tempted me." Just as Arabella's rationality inflames Glanville, who by such a response maintains her within the sexuality that rationality might otherwise threaten, so Brontë's depiction of women's boredom, misery, and ambition is perceived as just another story of seduction. 
category of woman is already necessarily degraded, her mind fettered by an ignorance that propriety dangerously confuses with innocence-an imbecility that delivers her over to the sexual designs of others. McCarthy and Brontë are also similar because Brontë too remains trapped within the destructive cultural logic McCarthy so easily accepts: that such results cannot be wholly innocent. She too ultimately winds up blaming woman for her fall, blaming the woman who tells tales, the woman writer. Like McCarthy, Brontë too implies that there remains a disturbing connection between the woman disgraced and that "mischief-making talebearer," the romancist-as if such writers do not merely describe but somehow create these dangerous fabrications.

Such narrative outlines are familiar. They are not the coinage of the nineteenth century alone but its inheritance from its literary predecessors, those eighteenth-century fathers (and mothers) of the novel. The heroine's plot in the eighteenth century describes this trajectory into ruin; the plots of such novels as Richardson's, for example, self-reflexively arise from the plots and subterfuges of those characters within them, the Lovelaces and Mr. B-s, who attempt to ensnare innocence by playing on ignorance. ${ }^{38}$ Wollstonecraft's critique in $A$ Vindication of the collapse of innocence and ignorance as strategic-a way to keep women preyed upon and powerless as they are exchanged among men-specifically lays the blame for the cultural construction of woman at the feet of the tale-bearers: she especially indicts sentimental romances as providing nothing but such plots, catering to ignorance, inflaming imagination at the expense of reason, and materially contributing to woman's degradation.

Yet Wollstonecraft, like Brontë, is a tale-bearer herself (and Brontë's phrase suggests the double bind for women writers, implying the way that even women's relation to storytelling seems defined in terms of the body-the "bearing" of tales echoing the bearing of children). The questions I posed earlier in the chapter

\footnotetext{
38It is the very play between ignorance and innocence-Clarissa's or Pamela's extraordinary blindness to the evil intentions of others places them in situations where their principled refusal to submit is their only defense-that constitutes the dramatic tension of their stories. And it's interesting that, for McCarthy (quoting Heine), Pamela's innocence is only an "anatomical chastity"-he locates this tension in terms of and on the site of the body (McCarthy, "Novels with a Purpose," 46).
} 
remain: as Mary Poovey has phrased it, how can a woman writer be a proper lady? The cultural construction of woman seems to foreclose any alternative to the one in which experience equals ruin; such, at least, are the assumptions not only of McCarthy but also of Wollstonecraft's critics (especially the outspoken Polwhele), who effectively censured her according to the logic that, if she had made a reputation as a writer, she had lost it as a woman.

It is precisely such logic that Catherine Gallagher has recently interrogated by turning again to the body of the woman, and its relation to (women's) writing. She opposes to the model of paternity and inheritance traditionally associated with authorship another model: the metaphor of author as whore. This association (not simply a product of the eighteenth or nineteenth century, she argues, but part of the Western tradition, going back to classic times) helps account for women's anxiety of authorship, for "when women entered the career of authorship, they did not enter an inappropriately male territory, but a degradingly female one." 39 According to Gallagher, unlike the father's "procreative Word," the prostitute's generative acts simply proliferate, but do not (re)produce: "The gender distinction in literary theory is . . . between the natural production of new things in the world and the 'unnatural' reproduction of mere signs. According to the father metaphor, the author generates real things in the world through language; according to the whore metaphor, language proliferates itself in a process of exchange through the author." 40 In this male economy of things and signs, a woman writer, unable to claim paternity, can occupy only a marginal, inherently alienated and disenfranchised position. She becomes a whore, a sterile purveyor of used (and useless) goods. For Gallagher, the metaphor of writer as whore is a metaphor of exchange alienated from productivity, writing from materiality. The differences she describes between it and the metaphor of writing as paternity-which takes its authority from its a supposedly firm grounding in, and creation out of, the solid facts of life-describe epistemological differences underlying what have

${ }^{39}$ Catherine Gallagher, "George Eliot and Daniel Deronda: The Prostitute and the Jewish Question," in Sex, Politics, and Science in the Nineteenth-Century Novel, Selected Papers from the English Institute, 1983-84, n.s. 10, ed. Ruth Bernard Yeazell (1986), 40.

40Gallagher, "George Eliot," 40, 41. 
often been seen in current critical debate as competing strategies of reading. This debate-about whether interpretations should emphasize "mere" signs or material conditions-is particularly important in feminist criticism: our different definitions of feminist politics seem to come down to whether we see woman more as construction or as material object, sign or body.

In implicitly arguing for the material grounding of (women's) writing, Gallagher's association of the prostitute with proliferating and ungrounded uncertainty seems to depart diametrically from the traditional construction of the prostitute, which aligns her directly through the supposed materiality of her body with material conditions and historical fact. I shall return at the end of this chapter to the differences within the construction of this figure-especially to Gallagher's revision of the traditional meaning of that figure, to discuss whether it is actually a revision at all. But I need to look first at the way the prostitute has, in practice, generally stood for the material, and to do so I turn now to Karl Marx, that emphasizer of material conditions.

The early writing of Marx contains examples in which the prostitute represents what he calls in another context "the world of things." ${ }^{11}$ In The Economic and Philosophic Manuscripts of 1844, Marx critiques naive (i.e., untheorized) communism as a regressive stage, which remains tied to private property, although it makes the possession of such property universal. Marx underwrites his argument through recourse to the figure of the prostitute; such universal private property, he writes:

finds expression in the brutish form of counterposing to marriage (certainly a form of exclusive private property) the community of women, in which a woman becomes a piece of communal and common property. It may be said that this idea of the community of women gives away the secret of this as yet completely crude and thoughtless communism. Just as the woman passes from marriage to general prostitution, so the entire world of wealth (that is, of man's objective substance) passes from the relationship of ex-

${ }^{41}$ Karl Marx, The Economic and Philosophic Manuscripts of 1844, trans. Martin Milligan and Dirk J. Struik, in Marx and Engels: 1843-44, vol. 3 of Karl Marx and Frederick Engels, Collected Works, 50 vols. projected (1975-), p. 272. 
clusive marriage with the owner of private property to a state of universal prostitution with the community. 42

The prostitute is a symbol for property, the thing possessed. At the same time, for Marx, prostitution is also the symbol for the workers' alienation from their labor-the people's "original sin," in which they had "nothing to sell except their own skins"43-which represents for him the way that "labour itself becomes an object." 44 The brilliance of Marx as an analyst of the material is precisely his emphasis on the way supposed abstractions, such as labor, become literal, become objects to be exchanged, entities producing effects.

42Marx, Economic and Philosophic Manuscripts, 294-95.

43Karl Marx, Capital: A Critique of Political Economy, ed. Frederick Engels (1906), 785 .

44Marx, Economic and Philosophic Manuscripts, 272. Marx continues the metaphor in which the prostitute represents the world of things and is herself an object by suggesting: "money is the procurer between man's need and the object, between his life and his means of life" (Economic and Philosophic Manuscripts, 323). That is, money provides the perverting access to the material world that changes man's relation to the material (to woman, for example; see his discussion of how man's [sexual] relation to woman figures his relation to the material world in a way that is "sensuously manifested, reduced to an observable fact" [Economic and Philosophic Manuscripts, 296]), and changes that relation from a natural to an economic one, makes woman into prostitute (although later Marx collapses the distinction between pimp and whore, calling money "the common whore, the common procurer of people and nations" [Economic and Philosophic Manuscripts, 324]). The way the prostitute figures both the material and the corruption of true relations with the material suggests the complexity of this figure in Marx's writing; her relation to money suggests the way she might also stand for the ungrounded exchanges of capitalism. Irigaray has examined the way the prostitute comes to symbolize the split for Marx and Engels between use and exchange value, suggesting an abstract quality in excess of her materiality-suggesting exchange itself. See Luce Irigaray, "Women on the Market" and "Commodities among Themselves," in her This Sex Which Is Not One, trans. Catherine Porter, with Carolyn Burke (1985), 170-91, 192-97. See also Luce Irigaray, Speculum of the Other Woman, trans. Gillian C. Gill (1985), 119-23. Yet, as my chapter argues, the prostitute becomes a symbol for such abstractions in order to try to ground them, to lend them her supposed materiality. This tendency to literalize without comment in Marx's thought (which infuses even his figurative language) seems to me to comment on the kind of complaint expressed by Foucault: that "while there are some very interesting things about the body in Marx's writings, Marxism considered as an historical reality has had a terrible tendency to occlude the question of the body, in favor of consciousness and ideology" ("Body/Power," Power/Knowledge: Selected Interviews and Other Writing, 1972-77, trans. Colin Gordon, Leo Marshall, John Mepham, Kate Soper, ed. Colin Gordon [1980], 58-59). 
Prostitution becomes for him the symbol of such literalness, of man's reification, his fall into the painful materialism of capitalism.

In literary analyses, the prostitute is so conventionally the shorthand for objective reality within history that reference to her inevitably introduces reference to historical evidence (even by those critics who seem least likely to read that way). ${ }^{45}$ It is just such attention to class and history, Cora Kaplan argues, that makes feminist analyses effective, that keeps them from simply being more re-plottings of the daughter's seduction. In an essay specifically critiquing a failure of feminism within Mary Wollstonecraft's work, Kaplan writes that feminist "appropriation[s] of modern critical theory-semiotic with an emphasis on the psychoanalytic-... must engage fully with the effects of other systems of difference than the sexual [systems such as class or race], or they too will produce no more than an anti-humanist avant-garde version of romance." 46 They will

unintentionally reproduce the ideological values of mass-market romance ... [ [in which] the other structuring relations of society fade and disappear, leaving us with the naked drama of sexual difference as the only scenario that matters. Mass-market romance tends to represent sexual difference as natural and fixeda constant, transhistorical femininity in libidinized struggle with an equally "given" universal masculine. ${ }^{47}$

45In the preface of Reading for the Plot, for instance, Peter Brooks sets up the plot of that study as a dialogue between formalism and psychoanalysis, yet the chapter in which he focuses on the figure of the prostitute, entitled "The Mark of the Beast," discusses in detail the historical and material determinants of the serial novel as a literary mode of production. See Peter Brooks, Reading for the Plot: Design and Intention in Narrative (1984); see xiii-xvi for his discussion of formalism, 143-70 for "The Mark of the Beast." Similarly, Jane Gallop, who has come almost to represent ahistoricism to critics impatient with such reading (such as Andrew Ross), ends her book, The Daughter's Seduction, with an uncharacteristic discussion of class, economic commerce, and history, within the context of a discussion of the governess. In its structure (its references to women's exchange and Lévi-Strauss, for example) this discussion repeats some of the standard arguments about prostitution-displacing, perhaps, such conventional consideration of material conditions from her earlier analysis of the Sadian whore, an analysis readers like Ross find shocking in its ignorance of these conditions. See Jane Gallop, "Keys to Dora," The Daughter's Seduction, 132-50; for her discussion of the Sadian whore, see 89-91. See also Andrew Ross, "Viennese Waltzes," Enclitic 8 (Spring/Fall 1984): 71-82.

46Cora Kaplan, Sea Changes: Essays on Culture and Feminism (1986), 148-49.

47Kaplan, Sea Changes, 148. 
By forcing the reader to confront the realities of class and history, Kaplan implies, the prostitute, that site where the economic and erotic must converge, dispels the delusions of romance, the blind desires that obscure the other plots in which women are entrapped.

It is precisely for her refusal to confront the example of the prostitute that Kaplan criticizes Wollstonecraft. Despite all her feminist impulses, Wollstonecraft remains for Kaplan entrenched in liberal bourgeois notions of gender and subjectivity that attempt to maintain the autonomy of the middle-class feminine individual by differentiating her from that specular other, the whore. In order to preserve the romance of the individual, Wollstonecraft falsely insists on "true" womanhood's difference from, rather than identification with, the de-individualized prostitute: for Wollstonecraft, as representative of her class, "'true womanhood' had to be protected from. . . the debased subjectivity and dangerous sexuality of the lower-class prostitute," Kaplan writes. "In A Vindication, workingclass women are quite unselfconsciously constructed as prostitutes and dirty-minded servants corrupting bourgeois innocence." 48

Similarly interested in material history and class, Mary Poovey agrees that an ignorance of such categories leads feminism-and Wollstonecraft-into dangerous romance, into a repetition of the traps for women that feminism and the woman writer hope to escape. ${ }^{49}$ Turning from $A$ Vindication to Wollstonecraft's novel, The Wrongs of Woman, Poovey points out, however, that Wollstonecraft does not simply ignore or revile the prostitute. The story of the prostitute Jemima offers "a radical, indeed feminist, story" - a "decidedly unsentimental" story that "has the potential to call into question both the organizational principles of bourgeois society and the sentimentalism that perpetuates romantic idealism" especially within the sentimental romance. ${ }^{50}$ Poovey argues that

\footnotetext{
${ }^{48}$ Kaplan, Sea Changes, 168, 169. For another discussion of the significance of prostitution within Wollstonecraft's political ideology which questions in passing our impulse to find twentieth-century political approaches more radical and advanced than Enlightenment positions, see Frances Ferguson, "Wollstonecraft Our Contemporary," in Gender and Theory: Dialogues on Feminist Criticism, ed. Linda Kaufman (1989), 51-62. This essay is a reply to Timothy J. Reiss, "Revolution in Bounds: Wollstonecraft, Women, and Reason," in Kaufman, Gender and Theory, 11-50.

49Poovey, The Proper Lady, 109.

50Poovey, The Proper Lady, 104, 103, 104.
} 
Wollstonecraft, because of her own individual position, is simply unable to develop such "revolutionary implications" of the demystification of romantic love and individual effort, the foregrounding of the way "the individual's situation-his or her position within class, gender, economics, and history-really delimits freedom and virtually defines the self.' "51 Wollstonecraft's reluctance to "relinquish the individualistic values tied up with the sentimental structure itself," to give up the romance of womanhood that promises her satisfaction and fulfillment especially in romantic love, Poovey argues, makes her break off Jemima's story and turn from the unmediated horrors of woman's material life that she begins to sketch there. 52

Material feminists such as Kaplan and Poovey provide an important perspective from which to read Wollstonecraft's work and the figure of the prostitute in cultural discourse. Prostitution is important to such readings because they see it not simply as metaphor but as referring to an important condition of women's reality. Sexuality separated from the mystifications of love or reproduction, relocated in terms of brute materialism and economics - the violence done to the body of the prostitute, the money paid her-also becomes in such readings a crucial metaphor for the treatment of women in general. Prostitution seems an effective focus for the reading Kaplan and Poovey advocate because it represents the condition in which romance (defined as sexual love) is shown to be a question of economics. To these critics, however, Wollstonecraft's treatment of the prostitute chooses romance over economics; to them, Wollstonecraft sacrifices that figure in order to make the prostitute's sexual commerce seem extraordinary and abnormal, rather than the type of the relations between the sexes.

Such denials, they argue, also determine the very structure of her writing; Mary Poovey suggests that the style of Wollstonecraft's language, especially its abstract diction, grows out of these ideological assumptions, out of her desire to "dematerialize" feminine desire-to avoid the bodily realities of sex and the physical consequences of class. ${ }^{53}$ Although I might question whether concrete diction is any more concrete-closer to its referent?-than other

51Poovey, The Proper Lady, 109.

52Poovey, The Proper Lady, 108.

53Poovey, The Proper Lady, 78. 
word choice, I want to continue along the direction these critics have charted to ask another question: what difficulties might there be for our feminist analyses in taking the prostitute as a symbol for the material? It seems to me that Wollstonecraft uses this figure not so much to emphasize the material herself but to confront just those problems of representation involved in such an emphasis.

An attention to those problems seems to me to give Wollstonecraft's writing its very shape. Just as the prostitute stands for the breakdown of the distinction between the public and the private (exposing supposedly intimate erotic encounters as simply another exchange within economic institutions), Wollstonecraft encodes that breakdown into her writing. Her insistence on the private might be not just wishful regression but also what Wollstonecraft claims it is, political strategy. A Vindication revises sentimental stereotypes precisely by insisting on them, repeating them with a difference. It is a political tract that quite deliberately takes the form of a conduct book, locating women's struggle in "a REVOLUTION in female manners" (VRW.13.317). The inseparable and radical equation of private and public is part of Wollstonecraft's political message-she writes insistently throughout $A$ Vindication that public virtues "must ever grow out of the private character" (12.279). Kaplan and Poovey importantly demonstrate how Wollstonecraft's insistence on private character may grow out of an unconscious desire for individual autonomy, but just as important are the moments in Wollstonecraft's work that show that her insistence also grows out of something else too: the quite explicit recognition that private character is itself an institution, a form of representation.

In The Wrongs of Woman, as in A Vindication, Wollstonecraft may be unable to imagine an alternative free of the representational constraints of the existing order, but she still recognizes that, within that order, all women are prostituted. ${ }^{54}$ Jemima's story es-

54In the letter appended to the "Author's Introduction" of The Wrongs of Woman, Wollstonecraft writes that her aim in the novel is "to show the wrongs of different classes of women, equally oppressive, though, from the differences of education, necessarily various" (Author's Introduction.74). Within the cultural structure she considers, all women are defined in terms of prostitution, and class differences register that similar characterization differently. Wollstonecraft suggests, for example, that the supposedly chaste women who inexorably assign guilt to lower-class prostitutes actually "assume, in some degree, the same character themselves" (VRW.8.249). The very ritual of a fashionable girl's coming out, for instance, is 
pecially makes clear the way romantic love is the mystification of economic transactions, played out on the body of the woman, and this lesson is not actually broken off; the rest of The Wrongs of Woman to some degree repeats it. Maria's husband marries her, has sex with her, even barters her, according to his need for money. The Wrongs of Woman is the fictional continuation of $A$ Vindication especially in its emphasis that bourgeois women, like Maria, and women of other classes, like Jemima, are connected through their status as bodies.

Yet Wollstonecraft's response to such a dynamic may be different from the ones materialist critics supply not because she cannot follow through on the critique she sketches, but because she recognizes problems within it. Even though in the author's introduction to $A$ Vindication, Wollstonecraft insists that she "shall be employed about things, not words!" (Introduction.82), the story of Jemima reveals how just such an emphasis on the material, when symbolized by the body of a woman, might continue rather than undo the violence done to women. Using the prostitute as a metaphor for material analysis, for a way to "materialize" writing, may be one more repetition of this figure's exploitation. On the one hand, Wollstonecraft's writing about the prostitute may insist that the reader pay attention to the body of the woman in order to learn some material lessons. On the other, however, her writing suggests that perhaps all that readers ever do is pay attention to the woman's body and that they need to confront some of the problems that arise from doing so.

Jemima's story shows that when prostitution is aligned with writing through the metaphor of the body, it can also be at the

another way "to bring [a woman] to market" (VRW.12.289), and it is just such insensibility produced by commercial speculation that Wollstonecraft finds obscene. In The Wrongs of Woman, she characterizes a marriage based on economics rather than passion as "a mere affair of barter . . . [involving] secrets of the trade" (10.153). The privileging of passion here may indeed be unironized and reveal Wollstonecraft's adherence to regressive, class-bound categories, her wish that some relations were outside economics, although, as Kaplan insists, the intricate interrelations between sexual drive and social organization make impossible any simple causality (i.e., assuming that class determines our representations of sexuality, or vice versa). Wollstonecraft's work makes available, however, some of the complexities of those interrelations, especially by insisting on them as questions of representation-that different (class) contexts make readers see things differently and make things different. 
expense of the category of woman. Jemima's body, to which she becomes reduced, is, throughout her story, an instrument to be written on by the characters within the story (a practice we cannot avoid continuing as critics when we use her as a metaphor for whatever purpose). ${ }^{55}$ Wollstonecraft, in fact, identifies different forms of marking on the woman as similarly exploitative. The violent blows with which Jemima's father "did not fail to leave the marks of his resentment on [her] body" (WW.5.104), and the ways she is later "branded with shame" (5.118) by her reputation as prostitute and thief, are similar to the real letters literally marked on her, when, during her apprenticeship, she "was sent to the neighbouring shops with Glutton, Liar, or Thief, written on [her] forehead" (5.106). Such decidedly unsentimental writing suggests the dangers to women of making metaphors literal, of insisting on some "real" category of woman as the vehicle for meaning, of making her the literal bearer of the tale.

Wollstonecraft's fiction provides some access to the danger to women involved in emphasizing the material in such a way. Early in Mary, Wollstonecraft presents a startling vignette which suggests that writing on the body of the woman necessarily does violence to it. Mary herself is figuratively impressed with an indelible image that both determines the course of her own story and is also the emblem for it: the image of a woman's mangled body.

\begin{abstract}
A little girl who attended in the nursery fell sick. Mary paid her great attention; contrary to her wish, she was sent out of the house to her mother, a poor woman, whom necessity obliged toleave her sick child while she earned her daily bread. The poor wretch, in a fit of delirium stabbed herself, and Mary saw her dead body, and heard the dismal account; and so strongly did it impress her imagination, that every night of her life the bleeding corpse presented itself to her when she first began to slumber. . . . The impression that this accident made was indelible. (M.2.6)
\end{abstract}

This short, stark vignette is in part a tale of economic distress (the mother forced to earn her daily bread), in direct contrast to Mary's-

\footnotetext{
${ }^{55}$ For another discussion of the relation between criticism and the figure of the prostitute as a marked body, see Nancy K. Miller, "Reading as a Woman: The Body in Practice," in The Female Body in Western Culture: Contemporary Perspectives, ed. Susan Rubin Suleiman (1986), 354-62.
} 
and Wollstonecraft's - romances. Such tragedies of labor and privation could be seen as the true story of womanhood, the antitheses of the frivolous romances that Mary's mother reads and Mary enacts. Yet this tale also might itself be a romance as well: it follows almost directly after the narrative tells us that Mary has such "a fondness for reading tales of woe... [that] made her almost realize the fictitious distress" (M.2.6), a juxtaposition that reasserts this vignette's own fictionality, the way that this too is a tale of woe introduced by Wollstonecraft into her own story. It calls attention to Mary's sympathetic (if not sentimental) response to it, suggesting that she might be trying, in her attitude, to make her experience conform to the expectations romance sets up. The chapter ends shortly thereafter by indicting Mary as "too much the creature of impulse" (M.2.7), and her reaction to this vignette might be considered romantically impulsive and excessive-the novel's inclusion of it itself using the body of a woman to produce this effect, as part of its own romantic detailing of Mary's exquisite moral sensibility. Being too easily impressed has conventionally been considered romantic; Poovey tells us that Maria, for example, is romantic precisely because she is (overly) responsive to her uncle's stories: "Because Maria has not personally experienced her uncle's disillusionment, she responds as contemporary moralists feared women 'naturally' respond to sentimental novels; she is 'imprinted' with sentiments as she projects herself, a heroine, into his text." 56 Yet Wollstonecraft herself also uses the metaphor of an indelible mark to critique this very attitude; Mary's silly mother is similarly struck by reading romances; their stories of love force on her too a "fatal image!" of a romantic life that makes her dissatisfied with her own (M.1.2), an excessive romanticism Wollstonecraft criticizes. Wollstonecraft goes on to lament in the letter appended to her preface to The Wrongs of Woman that inferior literary productions, full of such stage-effects, "may more forcibly impress the mind of common readers" (74) than more realistic stories. The doubleness of Wollstonecraft's attitude toward romance (her stories continue to make use of it even as they criticize it) means that despite her critique of the indelible image of women's sacrificed body as a 
danger of romance, that image underlies Wollstonecraft's own supposedly realistic writing as well.

The Wrongs of Woman has its own such fatal image, "her infant's image . . continually floating on Maria's sight" (1.75). ${ }^{57}$ The image of her daughter (murdered, she fears, to allow her husband to inherit her legacy), thus impressed on her, figures the pervasive sacrifice of women's bodies-Jemima's, Maria's, Maria's daughter's-to men's material gains. These fatal images pervade women's stories-both romantic tales and realistic tales of economic distress. Wollstonecraft's heroines are imprinted with this lesson, so that the woman's body, seen as a blank on which to inscribe, inscribes again and again in Wollstonecraft's fiction the dangers of doing so.

The repetition of such dismal accounts structures Wollstonecraft's fiction; her heroines, who helplessly repeat them, seem drawn to such scripts. The supposedly romantic and realistic characters are similar in this: like Mary in her fondness for tales of woe, Jemima notes that she " 'had often, in [her] childhood, followed a balladsinger, to hear the sequel of a dismal story, though sure of being severely punished for delaying to return" (WW.5.111). Jemima herself enacts a compulsive sequel, forcing her suitor to expel the servant he had made pregnant, just as she herself was originally expelled by her master (prompted by his wife) after he had ruined her. This servant, however, rather than choosing prostitution, commits suicide, and of all the misery in her story, Jemima seems most impressed by the fatal image of her corpse: "Let me not recal the horrid moment!-I recognized her pale visage" (5.116). This servant's story makes manifest the way women's choices are reduced to their bodies: they may either barter or destroy them.

${ }^{57}$ Maria is also "haunted by Mr. Venables' image, who seemed to assume terrific or hateful forms to torment me, wherever I turned.-Sometimes a wild cat, a roaring bull, or hideous assassin, whom I vainly attempted to fly; at others he was a demon, hurrying me to the brink of a precipice, plunging me into dark waves, or horrid gulphs" (WW.13.179). Interesting to my argument here is the way Venables's image emphatically refuses his bodily form, metamorphosing into almost anything but that. This may imply a revision of Wollstonecraft's earlier novel, in which the fatal image that floats on women's sight is most often that of their male lovers (M.5.13; 16.37; $18.40 ; 19.43 ; 25.57 ; 27.63)$. In her novels, Wollstonecraft seems to be working through the problem of how the representations of men and women relate to the representation of the body and to the essentializing tendency implicit in conjuring up the figure of the body. 
That Jemima forces a repetition of her own story is not surprising, for that story too is already itself a repetition, a replay of her mother's. Her corruption is attributed to her mother's fall- "I was born a strumpet; it ran in my blood" (5.108)—and her mother's story, with which Jemima begins her own, inspires further tale bearing throughout. Jemima's stepmother, for instance, spins out of it the malicious tale she tells Jemima's father; her stepmother's "'principal discourse [Jemima tells us] was to recount my faults, and attribute them to the wicked disposition which I had brought into the world with me, inherited from my mother' " (5.104). That a mother's tale is the only real inheritance she can pass on to her daughter is evident from Maria's story; Jemima's story goes on to emphasize that the only way women can gain interest and influence is by bearing such tales (Jemima's wicked master, for instance, gives her grudging assistance when he realizes the scandal that could be caused by her telling everyone that he has made her pregnant). Stories of violence enacted on women's bodies connect mothers and daughters who may share no other connection. Although Jemima blames her life of prostitution on her lack of a mother, for instance (just as the mother's absence leads to the nursery girl's death-a death self-imposed, suggesting the extent to which women bear within themselves the roles they are given), she is able to read her own life by reference to her mother's story, to give it meaning by fitting it into a tradition that gives her some connection with that mother.

Such a tradition is different from the male tradition; such stories differ from men's stories about women, not in how they find a way to refuse the body but in how they directly reveal that that body is the vehicle for and the currency of those stories, what makes meaning legible in them. As Wollstonecraft notes in $A$ Vindication, the woman's body is the payment woman must make to man for her maintenance, no matter how miserable, within the status quo (4.164-65). Such stories reveal clearly how man grants woman meaning only in terms of that body. The tale of woe Maria passes on to other women is what experience teaches her: that men pay attention not to such tales but only to her body-the attorney wishes to help her, not because he is persuaded by her sad narrative but because "my eloquence was in my complexion, the blush of seventeen" (WW.7.134). Similarly, Darnford originally comes to 
her rescue, defending her against Venables's slanders, because he observes, with "manly interest" that "my countenance told a very different story" (13.175).

Darnford's heroics are more for his own sake than Maria's; in criticizing her for investing him with romantic qualities he does not possess, the novel exposes that she is attractive to him because she allows him to pose as a hero. ${ }^{58}$ Darnford's abandonment of Maria at her adultery trial shows that men allow women to embody the loss of reputation in order to maintain or magnify their own. Early in their own courtship, Wollstonecraft chides Godwin for grounding poetic creations in her, creating poetry by enumerating her "perfections": "Do not make me a desk 'to write upon,' I humbly pray." 59 Wollstonecraft may object to Godwin's use of her as a foundation for his writing because in such transactions the woman conventionally disappears altogether. What was supposedly passion for her gets revealed as passion for something else, for what she critiques elsewhere as the desire to fill "a niche in the temple of fame," to rise above "the black rolling steam of time, that silently sweeps all before it into the shapeless void called-eternity" (VRW.9.261). ${ }^{60}$ The Wrongs of Woman especially exposes how men attempt to secure their reputations, their good names, by depriving women of theirs, by making use of their bodies. It is only when Maria's husband's "character in the commercial world was gone. He was considered ... on 'Change as a swindler" (WW.11.160) that he attempts to retrieve his good name by selling hers, selling her into prostitution by bartering her to an influential business associate, making use of Maria's body when all the rest of his goods are gone (11.162).

The contrast between (writerly) reputation and "the shapeless void called-eternity" comes back to the problems involved in

58When Maria begins to muse on Darnford's perfections, even before she has seen or knows very much about him, she herself realizes the way she is setting him up as a hero, and realizes "how difficult it was for women to avoid growing romantic, who have no active duties or pursuits" (WW.2.87).

59"To William Godwin, July 1, 1796," in Collected Letters, 331.

${ }^{60}$ That such relations between men and women are transactions of power is suggested by the description in $A$ Vindication of power in similar language: "Power, in fact, is ever true to its vital principle, for in every shape it would reign without control of inquiry. Its throne is built across a dark abyss, which no eye must dare to explore, lest the baseless fabric should totter under investigation" (10.264). 
using the prostitute as the site for material and historical criticism. Because the prostitute is so insistently a body, that figure may be used to attempt to connect and stabilize what Mary Jacobus calls the "chaotic, formless, and multitudinous" facts of history, wishfully to give a body to history itself. ${ }^{61}$ Yet history as form remains constructed, and constructed according to the same assumptions that plot our fictions-an identification made clear by The Infernal Quixote, a novel (published in 1801) that joined in the censure of Wollstonecraft's writing by having its heroine err not through reading sentimental romances but through reading $A$ Vindication and Godwin's Memoirs of Wollstonecraft's life-that is, through reading the history of women's oppression and the story of a woman with a history. Even Catherine Gallagher's analysis, which seems to relate the figure of the prostitute directly to such uncertainty and chaos, by aligning such uncertainty with that figure which has come to stand for brute materiality, may be said to allay the anxiety generated by uncertainty, to stabilize it through the very figure she chooses to represent the problem of representation. The prostitute stubbornly remains a metaphor for the body precisely because a focus on her body seems to do away with metaphor. By seeing the body as the site of discourse, the bearer of meaning, as all of us as critics increasingly do in this post-Foucauldian age, and by choosing the body of the prostitute, traditionally the bearer of disease as well as meaning, to represent our new historicism, we may be attempting to cure the ideological contagion that has plagued the writing of even the most committed feminist by quarantining it, marking the body of the woman as we used to mark the doorposts of sick houses, as the site of that exchange.

61Mary Jacobus, "The Law of/and Gender: Genre Theory and The Prelude," Diacritics 14 (1984): 52. Jacobus is discussing the way political revolution is in particular frequently embodied in the figure of a woman, given a woman's face, to make it readable. Her implication is that such figurations (attempt to) stabilize a subversion that nevertheless continues to undermine the structures of representation-both in literary texts and political institutions. I might argue instead that using the figure of the woman to embody subversion rather than stability (as certain critical approaches attempt to do) still uses this body as a figure and, hence, may not be all that different a strategy. 